\title{
STUDY AND ANALYSIS OF BIO-ENZYME BASED NATURAL PRODUCT
}

\author{
Harkeerat Singh, Aarti Prasad \\ K V NAL \\ Bengaluru
}

\begin{abstract}
Excessive usage of harmful chemical household products causing degradation of our ecosystem. The cleaning products used every day in house are made of many harmful and toxic elements which most of us are unaware and unconcerned. The study and test of lakes show water contains many chemicals from household detergents. Most of these chemicals cannot be removed by sewage treatment and remain in the water. These are taken by human, plants, animals and cannot be removed by excretion. This article will discuss the applications, usage, and methodology for the preparation of bio-enzyme.
\end{abstract}

Key words: Bio-enzyme, chemical, detergent, natural product

\section{INTRODUCTION}

Indian culture being multi-linguistic is also having the uniqueness of rich tradition of implementing natural products in daily usage. Present era with the advancement of technology and science many inventions have been made for our convenience and to improve the standard of living which in turn made us to forget the essence of natural products. Our likening for artificial products is due to convenience and ease of availability along with attractive packaging. We are unaware that most of these artificial products are prepared with the chemicals which are harmful to the eco-system [1]. News emanating such as frothing lake catching fire, low immunity and skin diseases, and sudden death of person can all be related to the harmful effects of excessive chemicals usage in our daily life.

The most prominent usage in our household is the cleaning agent which is containing many toxic and harmful elements. In this article the bio-enzyme based cleaning agent is discussed along with the preparation methodology. Further the effectiveness of the same having anti-bacterial and antifungal properties is validated with the lab based investigation which clearly demonstrates that bio-enzyme slows down the progression of bacterial growth.

\section{EFFECT OF CHEMICALS}

The detergent and phenyl used as cleaning agent contains lot of chemicals. Mostly chemicals such as sodium loreth sulphate, triclosan,1-4 dioxane formaldehyde, phalates, phosphate etc. Some of the harmful chemicals in detergents, floor cleaners and shampoos of most popular brands are Sodium laurel sulphateactually pesticides and herbicides which kill plants insets disturbing the ecological balance and are equally harmful for humans [2]. These chemical causes various harmful effects on to the body such as skin or eye irritation, nausea, breathlessness, dullness and even responsible for cancer. Further they harm environment by causing algae bloom harming aquatic life, air pollution and helping harmful bacteria to become resistant to the antibiotic. Some of the other chemicals are triclosan phosphorous 1-4 dioxine etc. are harmful to our ecosystem.

\section{BIO-ENZYME APPLICATIONS}

Most of the chemicals cannot be removed by sewage treatment and remain in the water. These are taken by human, plants animals and cannot be removed by excretion. Bio-enzyme is a natural product and cleaning agent made from bio-enzyme is mixture of concentrated vinegar or alcohol along with other organic compound[2]. The same can be made from the citrus food. The main applications of bio-enzyme based products are:

a. Useful for cleaning floor, toilet

b. Useful for laundry wash

c. Useful for personal care

d. Useful for anti-bacterial and anti-viral so for refrigeration, storage etc

e. Useful for pest control

f. Useful for neutralization of pesticide on fruits and vegetables 


\section{International Journal of Engineering Applied Sciences and Technology, 2019 \\ Vol. 4, Issue 8, ISSN No. 2455-2143, Pages 205-207 \\ Published Online December 2019 in IJEAST (http://www.ijeast.com)}

The multipurpose applications show the effectiveness of bio based products and can be used in day to day activities. A survey by the author was conducted to find out the reasons for the low usage of natural products. Figure 1 provides the various reasons and the corresponding percentage responsible for its low usage. It can be seen that mostly awareness and availability are the prime factors to be dealt with for its widespread usage.

\section{Percentage of people using \\ chemical and natural products}

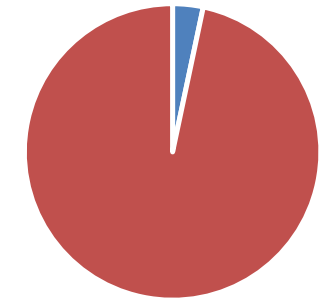

natural chemical

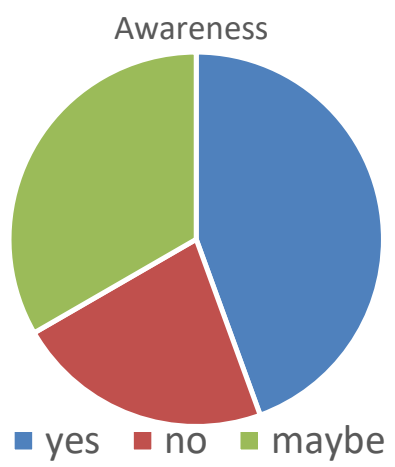

Fig1: Survey related with the Bio-enzyme based natural product(sample size:275)

\section{PREPARATION METHODOLOGY}

The procedure for the preparation of bio-enzyme is given below: Jaggery, citrus peel, water to be taken in the ratio of 1:3:10 added with little yeast and kept in the closed container. The same is to be kept in the dark place and after 2-3 days the lid to be opened for releasing the gases due to fermentation. The liquid obtained after 3 months from the container is the bio-enzyme (Fig 2).

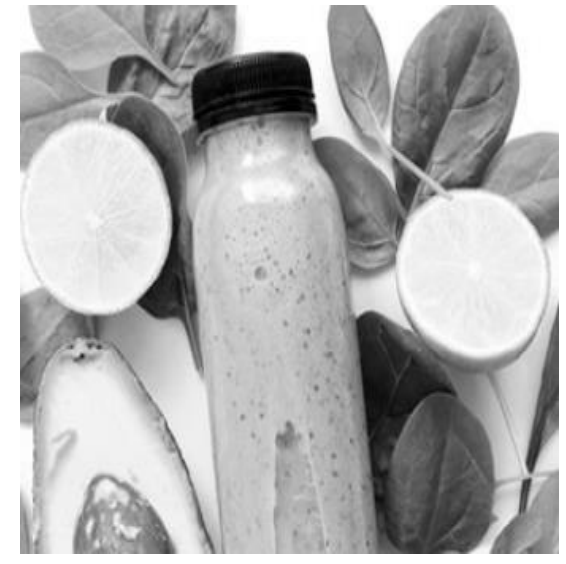

Fig2: Bio-enzyme preparation

The process is based on the formation of alcohol converted to acetic acid which eventually converts to bio-enzyme after reacting with vitamins and minerals[3-4].

\section{EFFECTIVENESS OF THE BIO-ENZYME}

The sample is provided to the lab and the generation of the report clearly shows that bio-enzyme based product stops the growth of the bacteria.
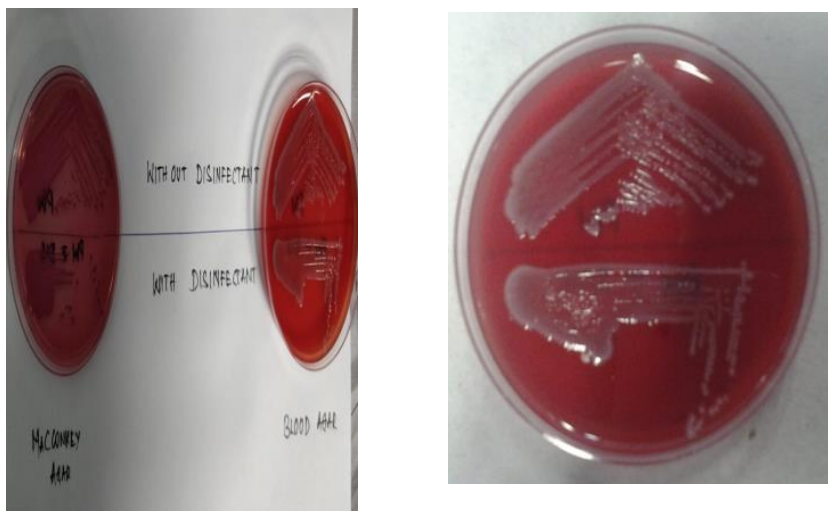

Fig3: Validation of anti-bacterial properties

The microscopic examinations (Fig3) show that the samples with bio-enzyme are having the properties of effectively removing bacteria. The effectiveness of bio-enzyme for antifungal properties is validated by having simple experiment of putting it on the bread and exposing it in the open environment. The results clearly show that after 2 weeks the growths of parasitic are minimal which is shown in Figure 4. 


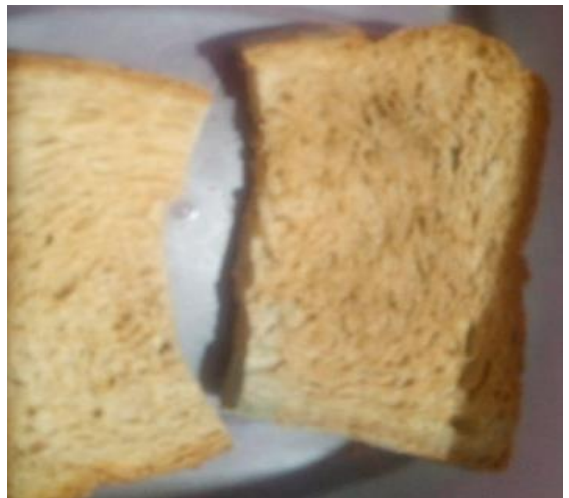

Fig4: Validation of anti-fungal properties

The above figure clearly demonstrates that natural product is far more effective than the artificial product.

\section{DISCUSSIONS}

This article demonstrates the bio-enzyme having effective anti-bacterial as well as anit-fungal properties. Simple methodology for the development of the bio based enzyme is discussed and the usage of the same shows that $50 \%$ reduction in the growth of bacteria. Another major advantage inherent in this natural product is the ecofriendliness. Contrary to the bio-enzyme based natural products, chemical based products such as detergent causes harmful effects to the human body. Resistance to various antibiotics is due to the excessive exposure of these chemicals in our daily usage. The major bottleneck is the popularization of these products. Various ways to popularize these products such as ease of availability, awareness, productionization for cost effectiveness and eventually making it mass movement. This will solve many problems arising due to excessive usage of chemicals and pave way for healthy and bright future for generations. This article focuses bio-enzyme for cleaning agent apart from exploring its anti-bacterial and anti-fungal properties.

Acknowledgements: We are thankful to Sh Manhoran and staff members of $\mathrm{K} \mathrm{V}$ NAL for all the support and encouragement provided in this study. Special thanks to my friend Mr Vidhus for his contributions. We are grateful to Dr Jiwan jyoti for providing guidance.

\section{REFERENCES}

1. Rachha Bhaterria, Disha Jain," Water quality assessment of lake water sustainable water resource management," 2016,2(2)

2. Bhavani Penmaster,D Chandra Sekhar,B S Diwakar, T V Nagalakshmi“" Effect of Bio enzyme in treatment of fresh water," International Journal of recent technology \& Engineering, ISSN 22773878, Vol 8,Issue 1S3,June 2019,pp 308-310

3. Peter K Robinson," Enzymes: principles \& biotechnological applications," Essays Biochem, 2015 Nov 2015,59:1-41

4. NCERT books 